\title{
Redirecting mouse $T$ hybridoma against human breast and ovarian carcinomas: in vivo activity against HER-2/neu expressing cancer cells
}

\author{
AD Gritzapis', A Mamalaki², A Kretsovali ${ }^{3}$, J Papamatheakis³ , M Belimezi ${ }^{2}$, SA Perez', CN Baxevanis*,I \\ and M Papamichail'
}

'Saint Savas Cancer Hospital, Cancer Immunology and Immunotherapy Center, 171 Alexandras Ave, 11522 Athens, Greece; ${ }^{2}$ Department of Biochemistry, Hellenic Pasteur Institute, Athens, Greece; ${ }^{3}$ Foundation for Research and Technology, Institute of Molecular Biology and Biotechnology, Heraklion, Crete

Chimeric receptors comprising of the T-cell receptor- $\zeta$ cytoplasmic signalling chain fused to an extracellular ligand-binding domain of a single-chain antibody (scFv) have served as effective tools for redirecting cytotoxic T lymphocytes (CTL) against tumour cells. In this report, we constructed a chimeric scFv/ל gene composed of the variable regions of an HER-2/neu-specific monoclonal antibody (MAb) joined to the TCR- $\zeta$ chain. The scFv(anti-HER-2/neu)/ $\zeta$ chimeric gene was successfully expressed as a functional surface

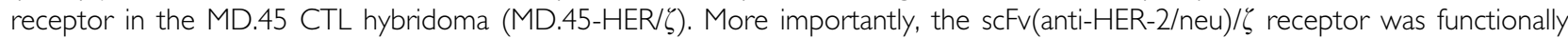
active, since it triggered cytokine secretion by the MD.45-HER/ $\zeta$ cells upon recognition of HER-2/neu-positive $(+)$ tumour cell lines, or primary tumour cells from patients with HER-2/neu ${ }^{+}$cancers. The MD.45-HER/ $\zeta$-transduced cells also lysed HER-2/neu ${ }^{+}$target

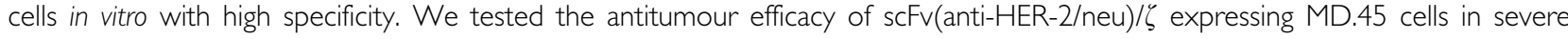
combined immunodeficiency disease mice/human and murine tumour models. The adoptively transferred MD.45-HER/ $\zeta$ cells both slowed significantly the growth of human FM3 melanoma or murine ALC leukaemic cells both transfected to express HER-2/neu.

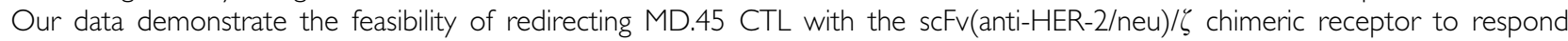
specifically against HER-2/neu expressing tumour cells in vitro and in vivo. Moreover, they make it likely that $T$ cells transduced with the same chimeric gene might be utilised in the treatment of patients with $\mathrm{HER}-2 / \mathrm{neu}^{+}$tumours.

British Journal of Cancer (2003) 88, 1292-1300. doi:I0.1038/sj.bjc.6600888 www.bjcancer.com

(C) 2003 Cancer Research UK

Keywords: chimeric receptor; cancer immunotherapy; HER-2/neu

A general limitation in the use of cellular adoptive immunotherapy is the difficulty in obtaining high numbers of lymphocytes specifically responding to autologous tumour cells. Nevertheless, in some cases, monoclonal antibodies (MAb) against tumourassociated antigens have been successfully generated (Abken et al, 1998). One approach, merging T-cell functions with antibody specificity, was to create chimeric receptors composed of a singlechain variable domains of MAb (scFv) fused to signalling $\zeta$-chain of the T-cell receptor (TCR) (Moritz et al, 1994; Altenschmidt et al, 1997; Brocker and Karjalainen, 1997; Maher et al, 2002; Niederman et $a l, 2002)$ or the $\gamma$-chain of the low-affinity receptors for IgG (Fc $\gamma$ RIII) (Eshhar et al, 1993, 2001; Hwu et al, 1995; Roberts et al, 1998) or IgE (FceRI) (Weijtens et al, 1996; Haynes et al, 2001). Introduction of such chimeric genes into $\mathrm{T}$ cells enables them to respond in an MHC-independent fashion to an antigen-specific trigger via these receptors by cytokine production (Altenschmidt et al, 1997; Eshhar et al, 2001; Maher et al, 2002) and tumour cell lysis (Eshhar et al, 1993; Moritz et al, 1994; Hwu et al, 1995; Weijtens et al, 1996).

*Correspondence: Dr CN Baxevanis; E-mail: cacenter@otenet.gr Received 10 October 2002; revised 31 January 2003; accepted 4 February 2003
The HER-2/neu oncogene (also known as ErbB-2) encodes a $185 \mathrm{kDa}$ transmembrane protein-receptor with tyrosine kinase activity and extensive homology to the epidermal growth factor receptor (Hung and Lau, 1999). HER-2/neu is ubiquitously expressed in many epithelial tumours and known to be overexpressed in approximately $30 \%$ of all ovarian and breast cancers (Slamon et al, 1989, 2001), 35-45\% of all pancreatic carcinomas (Yamanaka et al, 1993) and up to $90 \%$ of colorectal carcinomas (Maxwell-Armstrong et al, 1998) and this overexpression was shown to correlate with aggressiveness of malignancy and poor prognosis (Slamon et al, 1989; Pauletti et al, 1996). The HER-2/neu protein appears to be immunogenic because T-lymphocyte responses to both MHC class I- and class II-restricted epitopes have been observed (Yoshino et al, 1994; Fisk et al, 1995; Peiper et al, 1997; Brossart et al, 1998; Rongcun et al, 1999; Sotiriadou et al, 2001; Baxevanis et al, 2002; Perez et al, 2002). However, the use of such peptide epitopes for vaccination studies is limited to only those patients who express the appropriate MHC class I and class II alleles. The generation of $\mathrm{T}$ lymphocytes with a grafted MHC-independent recognition specificity for HER-2/neu expressing tumour cells could probably circumvent this problem. To this end the $\zeta$-chain of the TCR was linked with a scFv derived from a $\mathrm{MAb}$ directed against the human ErbB-2 receptor (Moritz et al, 1994; Altenschmidt et al, 1997). The $\operatorname{scFv}(\operatorname{ErbB}-2) / \zeta$ fusion gene 
was stably expressed in murine $\mathrm{T}$ lymphocytes that subsequently could recognise and lyse either mouse cell lines transfected to express the human ErbB-2 receptor or the human breast cancer MDA-MB453 cell line constitutively expressing ErbB-2 (Moritz et al, 1994; Altenschmidt et al, 1997). The same chimeric construct was recently used for redirecting a human NK cell line against HER-2/neu ${ }^{+}$tumours (Uherek et al, 2002).

In the present study, we constructed a novel HER-2/neu recognising chimeric receptor by fusing a $\mathrm{scFv}$ derived from an anti-human HER-2/neu MAb produced by the HB8696 hybridoma with the $\zeta$-chain of the TCR. Such chimeric genes were stably transduced in the murine MD.45 cytotoxic T lymphocytes (CTL) hybridoma, which could specifically recognise and lyse in vitro HER-2/neu expressing human tumour cell lines as well as metastatic tumour cells from different types of cancer. The transduced MD.45 CTL were also active in vivo in that they slowed tumour growth in severe combined immuno deficiency disease (SCID) mouse/human tumour models. Our data support

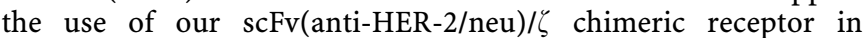
protocols related to combined cellular and gene therapy of cancer.

\section{MATERIALS AND METHODS}

\section{Patients}

Patients with metastatic breast and ovarian adenocarcinomas (stages III and IV) whose tumours expressed HER-2/neu (four of 17 examined; breast $\mathrm{Ca}, n=2$; ovarian $\mathrm{Ca}, n=2$ ) were included in this study. Ascites from these patients collected during routine aspirations were provided by the Oncology Department of Hippocration State Hospital and the Pathological Clinics of Saint Savas Cancer Hospital under the Institutional Review Boards of both Institutions.

\section{Cell lines}

The human breast cancer SKBR3 and ovarian cancer SKOV3 cell lines both expressing HER-2/neu (Brossart et al, 1998; Sotiriadou et al, 2001) as well as the Raji (Burkitt's lymphoma) and K562 (erythroleukemia) cell lines were purchased from the American Type Culture Collection (ATCC) (Manassas, VA, USA). The mouse hybridoma cell lines Myc-9E10.2 secreting a c-myc-specific MAb (Evan et al, 1985) and HB8696 secreting the MAb 520C9 which recognises the human c-ErbB-2 oncoprotein (Ward et al, 1989; Shi et al, 1991) were also purchased from the ATCC. The MD.45 CTL hybridoma of BALB/c origin was kindly provided by Dr Z Eshhar (The Weizmann Institute of Science, Rehovot). The human FM3 melanoma cell line and the murine ALC lymphoma cell line were kindly provided by Dr J Zeuthen (Danish Cancer Society Research Center, Copenhagen) and by Dr R Kiessling (Microbiology and Tumour Biology Center, Karolinska Institute, Stockholm) respectively. The ALC cell line was grown in vivo as ascites by serial passages in C57BL/6 syngeneic mice. All other cell lines were grown in RPMI-1640 supplemented with $10 \%$ fetal bovine serum (Life Technologies, Gaithersburg, MD, USA), $2 \mathrm{~mm}$ L-Glutamine and $50 \mu \mathrm{g} / \mathrm{ml}$ gentamycin (both from Sigma, St Louis, MO, USA) (complete medium).

\section{Isolation of tumour cells}

This was performed as recently described (Baxevanis et al, 2000). Ascites were centrifuged at $400 \mathrm{~g}$ for $5 \mathrm{~min}$ to sediment cells, which were further placed on top of a 75\% Ficoll-Hypaque gradient, overlaid on $100 \%$ Ficoll-Hypaque, and spun at $700 \mathrm{~g}$ for $25 \mathrm{~min}$. Tumour cells were collected from the top of $75 \%$ Ficoll-Hypaque and cryopreserved in liquid nitrogen until ready for use. At that time, cells were carefully thawed, slowly diluted in RPMI-1640 (Life Technologies, Gaithersburg, MD, USA) and washed. Tumour cells were assayed only if their viability was over $80 \%$. Phenotype analysis showed that all tumours were positive after staining with an anti-HER-2/neu MAb (clone Neu 24.7) and anti-mouse FITC (both, Becton Dickinson Mountain View, CA, USA) (range of HER2/neu expression: 18-92\%; see also 'Results').

\section{Construction of $s c F v($ anti-HER-2/neu)}

Total cellular RNAs were isolated from hybridoma cells HB8696 with the hot-acid phenol method (Brown and Kafatos, 1988; Mamalaki et al, 1993). Specific first-strand VH- and VL-cDNAs were synthesised by the primer extension method using M-MLV reverse transcriptase (Stratagene) and specific oligonucleotide primers according to EMBO Practical curse (1991). For the construction of $s c F v$ fragment of anti-HER-2/neu, we amplified specifically the VH- and VL-cDNAs that were then assembled as a scFv fragment as described (Mamalaki et al, 1993), by using Taq DNA polymerase (Minotec, Heraclion, Greece). The assembled $\mathrm{scFv}$ fragment was inserted into the phagemid pHEN1 (Hoogenboom et al, 1991) which was used to transform E. coli HB2151. The pHEN1 phagemid contains the c-myc tag peptide and the produced $\mathrm{scFv}$ is thus a tag antibody fragment. All DNA manipulations were performed according to previously described techniques (Kabat et al, 1991). DNA sequences were determined by the dideoxy-chain termination method (Sanger et al, 1977) using Sequenase version 2.0 (United States Biochemical Cleveland, $\mathrm{CH}$ ).

\section{Expression and purification of $\operatorname{scFv}($ anti-HER-2/neu) fragment}

HB2151 cells transformed with the pHEN1-scFv(anti-HER-2/neu) phagemid were grown at $25^{\circ} \mathrm{C}$ in $2 \times \mathrm{TY}$ medium containing $100 \mu \mathrm{g} / \mathrm{ml}$ ampicillin and $1 \%$ glucose. Soluble antibody fragments were isolated from the culture supernatants after induction with $1 \mathrm{~mm}$ IPTG for $16 \mathrm{~h}$. Expression of scFv antibody fragments was assessed by size analysis and immunoreactivity. Supernatants $(15 \mu \mathrm{l})$ from the induced cultures were analysed by electrophoresis on $12 \%$ SDS-polyacrylamide gels (Laemmli, 1970) and the proteins electrotransferred onto Hybond-C membranes (The Radiochemical Centre Amersham, UK) for immunoblotting. Soluble scFv fragments were detected using a serum-free hybridoma culture supernatant containing MAb 9E10, directed against the c-myc tag, and HRP-conjugated goat anti-mouse IgG (1:500 dilution) (DAKO A/S Glostrup Denmark), as previously described (Hoogenboom et al, 1991). The tagged scFv was purified on a protein A-Sepharose column using the anti-c-myc tag MAb 9E10, as previously described (Tsantili et al, 1999) .

\section{Immunofluorescence analysis of $\operatorname{scFv}($ anti-HER-2/neu) binding on tumour cell lines}

This was performed in two steps: at first, tumour cells were harvested and washed in PBS. Then an amount of $100 \mu \mathrm{l}$ of $1: 10$ diluted $s c F v($ anti-HER-2/neu) was added per one million cells and incubated on ice for $45 \mathrm{~min}$. In the second step, tumour cells were extensively washed to remove excess of $\mathrm{scFv}$ (anti-HER-2/neu) and then incubated for $30 \mathrm{~min}$ on ice with anti-myc MAb 9E10 followed by an additional $30 \mathrm{~min}$ incubation with FITC-conjugated antimouse Fab ( $1: 20$ dilution) (DAKO). After two washes in PBS, cells were analysed on a FACScan (Becton Dickinson) flow cytometer and calculated using the LYSYS II software (Becton Dickinson).

\section{Construction of the $\operatorname{scFv}($ anti-HER-2/neu $) / \zeta$ chimeric gene}

To construct the $\mathrm{scFv} / \zeta$ chimeric receptor we used the eukaryotic expression vector pCDNA3 (Invitrogen). The scFv was amplified by PCR from the pHEN1 vector and cloned between the Hind III and BamHI sites. Next, a leader peptide sequence from Ig heavy 
chain was synthesised in vitro and linked to the scFv via the inherent Pst I site. The $\mathrm{CD} 3 \zeta$ chain containing 3 aa extracellular sequence in addition to the transmembrane and cytoplasmic portion was amplified from the human cDNA clone kindly provided by Dr GC Tsokos (Walter Reed Army Institute of Research, Washington DC, USA) and cloned between BamHI and EcoRI in frame to the scFv. We also inserted a Flag epitope in the $B a m \mathrm{H} 1$ site in order to monitor the expression of the product. The

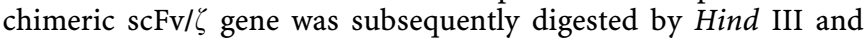
EcoRI and cloned (as a blunt fragment) into the retroviral vector pLRNL containing the long terminal repeat from Moloney murine leukaemic virus and a neomycin resistance gene. The retroviral constructs were transfected into the amphotropic cell line Phoenix (Pear et al, 1993) using $\mathrm{CaPO}_{4}$. A stable amphotropic packaging cell line, Phoenix, was obtained after G418 selection. The amphotropic virus supernatants produced had a viral titre of approximately $5 \times 10^{3} \mathrm{CFU} \mathrm{ml}^{-1}$, determined on the basis of neomycin resistance of infected NIH-3T3 cells. Such supernatants were collected and stored at $-20^{\circ} \mathrm{C}$.

Gene transduction and selection of gene-transduced cells This was performed as described previously (Weijtens et al, 1996). In brief, $2 \times 10^{6}$ cells of the MD.45 hybridoma cell line were cocultured for $72 \mathrm{~h}$ with a $70-80 \%$ confluent irradiated $(2500 \mathrm{rad})$ monolayer of virus pLRNLscFv(anti-HER-2/neu)/ producing Phoenix cells in culture medium supplemented with $4 \mu \mathrm{g} \mathrm{ml}^{-1}$ polybrene (Sigma Chemical Co., St Louis, MO, USA) and $500 \mathrm{IU} \mathrm{ml}^{-1}$ rIL-2. Subsequently, the gene-transduced MD.45 population (MD.45-HER/ $/ \zeta$ ) was selected for 4 days in culture medium containing $1 \mathrm{mg} \mathrm{ml}^{-1} \mathrm{G} 418$, followed by an additional round of selection (5 days) in medium containing $0.4 \mathrm{mg} \mathrm{m}^{-1}$ G418. After selection, the MD.45-HER/ $\zeta$ cells were expanded in round-bottom 96-well microtitre plates (Costar, Cambridge, MA, USA) at $37^{\circ} \mathrm{C}$ in $5 \% \mathrm{CO}_{2}$ in the presence of feeder cells, which consisted of irradiated $(2500 \mathrm{rad})$ allogeneic EBV-transformed

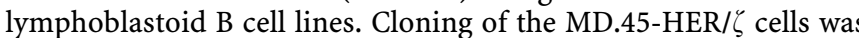
performed by limiting dilution at 3,1 and 0.3 cells well $^{-1}$ in the presence of feeder cells in RPMI-1640 culture medium supplemented with $10 \%$ FCS, $300 \mathrm{IU} \mathrm{ml}^{-1}$ rIL-2, $4 \mathrm{mM}$ L-glutamine, antibiotics and $1 \mu \mathrm{g} \mathrm{ml}^{-1}$ PHA (Sigma). Mock-transduced MD.45 cells (MD.45-mock) were generated by transducing the parental MD.45 cell line with the vector (i.e., pLRNL) alone.

\section{Transfection of the FM3 and ALC cell lines}

This was performed as described recently (Perez et al, 2002). In brief, FM3 melanoma cells were cotransfected with a pSV2-c-erbB2 construct (kindly provided by Dr. Mien-Chie Hung, Anderson Cancer Center, Houston, TX, USA) and a pSV2neo plasmid using DNA-CaPO ${ }_{4}$ coprecipitates. Selection with G418 was performed 2 days later, followed by cloning and subcloning of FM3 cells expressing HER-2/neu (referred to as FM3-HER). The same procedure was followed for transfecting the ALC cells with the pSV2-c-erbB2 construct (referred to as ALC-HER). Mock-transfectants of FM3 (FM3-mock) and ALC (ALC-mock) were generated by transfecting the parental cell lines with the plasmid (i.e., pSV2) alone.

\section{Expression of the chimeric $\operatorname{scFv}($ anti-HER-2/neu $) / \zeta$ gene}

Expression of the $\operatorname{scFv}($ anti-HER-2/neu)/ $\zeta$ on the surface of transduced MD.45 cells was evaluated by indirect immunofluorescence staining using the anti-Flag MAb (Sigma) and FITClabelled anti-mouse $\mathrm{Fab}^{\prime}$ antibody. Data were analysed and calculated as above.

\section{Functional assays}

These included cytokine production and cytotoxicity: transduced MD.45 cells $\left(10^{6}\right)$ were cultured with $10^{6}$ HER-2/neu ${ }^{+}$or HER-2/ neu $^{-}$cell lines in 24-well plates (Costar) for $24 \mathrm{~h}$. Following incubation, supernatants were harvested and spun to remove cell debris. Levels of cytokine production (IL-2 and IFN- $\gamma$ ) were measured by ELISA (Diaclone Research, Besancon, France) according to the manufacturer's instructions.

Cytotoxicity mediated by the MD.45-transduced effectors against tumour HER-2/neu ${ }^{+}$or HER-2/neu ${ }^{-}$targets was determined as described (Baxevanis et al, 2000). The percentage of cytotoxicity was calculated according to the following formula: \% lysis $=100$ (test ${ }^{51} \mathrm{Cr}$ release - spontaneous ${ }^{51} \mathrm{Cr}$ release $) /(\max -$ imum ${ }^{51} \mathrm{Cr}$ release-spontaneous ${ }^{51} \mathrm{Cr}$ release). Cytotoxicity values were considered to indicate significant recognition of a target, when the differences between mean values (from triplicate analyses) for percent lysis of the particular target (e.g., HER-2/ $\mathrm{neu}^{+}$tumour cell targets) and HER-2/neu ${ }^{-}$targets were equal to or higher than $10 \%$ at an $\mathrm{E}: \mathrm{T}$ ratio of $20: 1$ and statistically significant $(P<0.05)$.

\section{Tumour therapy model}

All the in vivo experimentations were carried out with approval form the ethical committee of St Savas Cancer Hospital and met all the standards required by the UKCCCR guidelines (Workman et al, 1998). The tumour therapy model was performed as follows: on day 1, CB-17 Prkdcscid /J (BALB/c scid) mice (Jackson Laboratory, Bar Harbor, Maine, Germany) 7-9 weeks

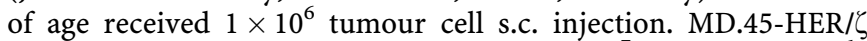
or MD.45-mock CTL was injected i.p. $\left(1 \times 10^{7}\right.$ cells injection $\left.^{-1}\right)$ on three consecutive days (starting on day 1). Total observation was over 120 days. The observation was terminated with the euthanasia of mice when the tumour mass grew up to $1.5 \mathrm{~cm}$ in diameter.

\section{RESULTS}

\section{Construction of $\operatorname{scFv}($ anti-HER-2/neu)}

Specific VL- or VH-cDNAs of hybridoma HB8696 mRNA, enzymatically amplified, were assembled as scFv antibody fragment and cloned into pHENI vector (Hoogenboom et al, 1991). The primary structure of various clones was analysed by DNA sequencing. Figure $1 \mathrm{~A}$ shows the cDNA sequence and the deduced amino-acid sequences corresponding to the $\mathrm{VH}$ region of $\mathrm{MAb}$ $520 \mathrm{C}$. Sequence comparison showed that the $\mathrm{VH}$ region of $\mathrm{MAb}$ $520 \mathrm{C} 9$ is a member of the subgroup IIA according to Kabat et al (1991). The complementarity-determining region 2 (CDR2) is long, containing 17 amino-acid residues. Figure 1B shows the cDNA sequence and the deduced amino-acid sequences corresponding to the VL region of MAb 520C9. Sequence comparison showed that the VL region is a member of the Vk group (Kabat et al, 1991).

\section{Reactivity of the anti-HER-2/neu scFv with tumour cell lines and primary tumour cells}

Binding of the $\mathrm{scFv}$ (anti-HER-2/neu) on tumour cells was determined by immunofluorescence and FACS analysis. Cell immunofluorescence was performed with ALC and FM3 tumour cell lines transfected to express HER-2/neu (ALC-HER and FM3HER, respectively), their mock transfectants and with the SKBR3 and SKOV3 tumour cell lines constitutively expressing HER-2/neu. Primary HER-2/neu ${ }^{+}$tumour cells from patients with metastatic breast (Br-1, Br-2) and ovarian (OVA-1, OVA-2) cancer were also analysed. The Raji and K562 cell lines, not expressing HER-2/neu, 
A

GAGGTGCAGCTGCAGGAGTCAGGGCCTGAGCTGAAGAAGCCTGGAGAGACAGTCAAGATC GluValGlnLeuGlnGluSerGlyProGluLeuLysLysProGlyGluThrVallys Ile

$\begin{array}{lllll}1 & 5 & 10 & 15 & 20\end{array}$

TCCTGCAAGGCTTCTGGATATAC $\$$ TTCGCAAACTATGGAATGAAdTGGATGAAGCAGGCT SerCysLysAlaSerGlyTyrTh PheAlaAsnTyrGlyMETAsnTrpMETLysGlnAla 21 25 30

35 CDR2

CCAGGAAAGGGTTTAAAGTGGATGGG ProGlyLysGlyLeuLysTrpMETGly TrpIleAsnThrTyrThrGlyGlnSerThrTyr $\begin{array}{lllll}41 & 45 & 50 & 55 & 60\end{array}$

GCTGATGACTTCAAGGAACGGTTTGCCTTCTCTTTGGAAACCTCTGCCACCACCGCCCAT AlaAspAspPheLysGluArgPheAlaPheSerLeuGluThrSerAlaThrThrAlaHis $\begin{array}{lllll}61 & 65 & 70 & 75 & 80\end{array}$

TTGCAGATCAACAACCTCAGAAATGAGGGCTCGGCCACATATTTCTGTGCA $\longdiv { \text { AGACGATTT } }$ LeuGlnIleAsnAsnLeuArgAsnGluGlySerAlaThrTyrPheCysAlaArgArgPhe

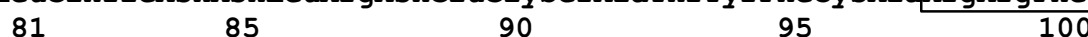

CDR3

GGGTTTGCTTACTGGGGCCAAGGGACCACGGTCACCGTCTCCTCA GlyPheAlaTyrTrpGlyGlnGlyThrThrValThrValserSer

\begin{tabular}{llll}
\hline 101 & 105 & 110 & 115
\end{tabular}

\section{B}

GACATTGAGCTCACCCAGTCTCCAGCCTCCCTTTCTGCGTCTGTGGGAGAAACTGTCACC AspIleGluLeuThrGlnSerProAlaSerLeuSerAlaSerValGlyGluThrValThr 1 10 15 20 ATCACATG CGAGCAAGTGGGATATTCAOAATTATTTAGCATGGTATCAGCAGAAACAG IleThrCy\$ArgAlaSerGlyAsnIleHisAsnTyrLeuAlaTrpTyrGlnGlnLysGln 21 25

CDR2

35

40

GGAAAATCTCCTCAGCTCCTGGTCTATTATACAACAACCTTAGCAGATGGTGCGCCATCA GlyLysSerProGlnLeuLeuValTy TyrThrThrThrLeuAlaAspGlyAlaProSer $\begin{array}{llrrr}41 & 45 & 50 & 55 & 60\end{array}$

AGGTTCAGTGGCAGTGGATCAGGAACACAATATTCTCTCAAGATCAACAGCCTGCAACCT ArgPheSerGlySerGlySerGlyThrGlnTyrSerLeuLysI leAsnSerLeuGlnPro $\begin{array}{lllll}61 & 65 & 70 & 75 & 80\end{array}$ GAAGATTTTGGGAGTTATTACTGPAACATTTTTGGAGTACTCCTCGGACGTTCGGTGGA GluAspPheGlySerTyrTyrCy\$GlnHisPheTrpSerThrProArgThrPheGlyGly $\begin{array}{lllll}81 & 85 & 90 & 95 & 100\end{array}$ $+60$

GGGACCAAGCTGGAAATAAAACGG
GlyThrLysLeuGluIleLysArg
$101 \quad 105$

Figure I Nucleotide and deduced protein sequences of the heavy (A) and light (B) chain variable domain of MAb 520C9. The CDRs I, 2 and 3 are indicated.

were included as negative controls. As shown in Figure 2, the ALC-HER, FM3-HER, SKBR3 and SKOV3 tumour cell lines were positive in immunofluorescence staining with the scFv(anti-HER$2 /$ neu) and anti-myc MAb plus FITC-anti-mouse $\mathrm{Fab}^{\prime}$ system $(86 \%, 68 \%, 100 \%$ and $89 \%$, respectively) and so did the primary tumour cells from metastatic breast (Br-1, 92\%; $\mathrm{Br}-2,27 \%)$ and ovarian (OVA-1, 81\%; OVA-2, 18\%) cancers. In contrast, ALCmock and FM3-mock as well as Raji and K562 cell lines did not show positive staining demonstrating the ability of our scFv to specifically bind on HER-2/neu ${ }^{+}$cells.
Expression of the chimeric scFv(anti-HER-2/neu $) / \zeta$ gene

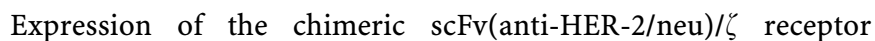
selective for $\mathrm{HER}-2 / \mathrm{neu}^{+}$tumour cells was performed by constructing one continuous molecule comprising gene segments of the variable region of the murine anti-HER-2/neu MAb produced by the HB8696 hybridoma and the signal-transducing human TCR- $\zeta$ chain transmembrane and intracellular region. Introduction of the chimeric scFv(anti-HER-2/neu) $/ \zeta$ gene into the MD.45-murine CTL hybridoma, resulted in the expression of the 

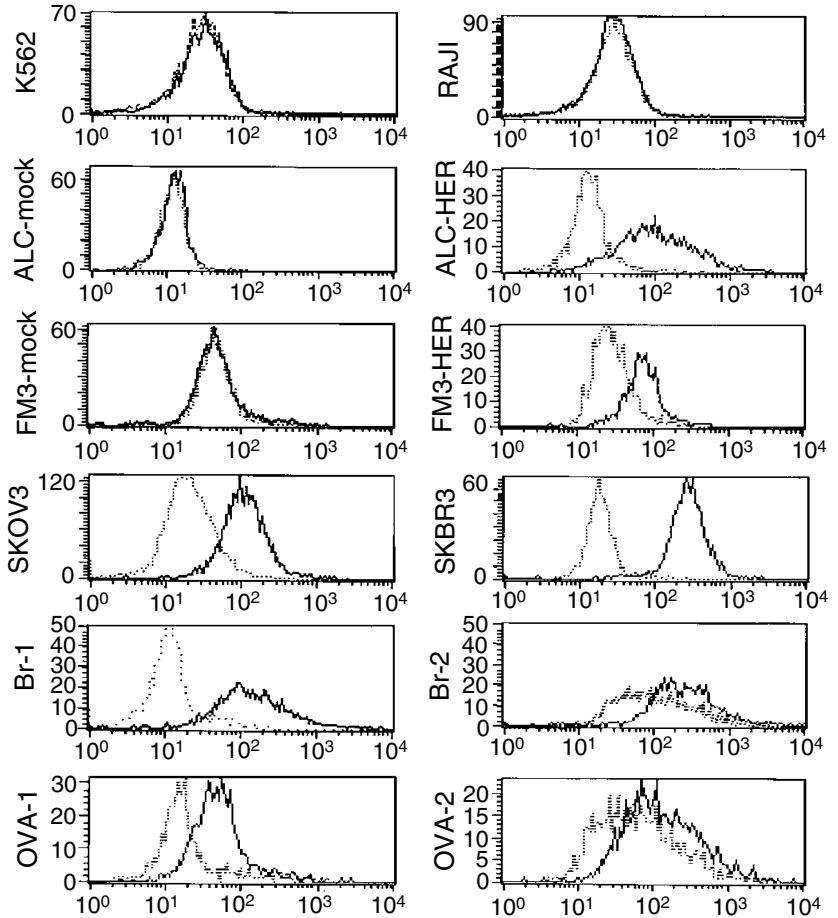

Figure 2 FACS analysis of immuofluorescence staining of HER-2/neu (ALC-HER, FM3-HER, SKBR3, SKOV3) and HER-2/neu ${ }^{-}$(ALC-mock, FM3mock, Raji, K562) tumour cell lines, treated with scFv(anti-HER-2/neu) and anti-myc MAb plus FITC-labelled anti-mouse Fab' antibody. Ova-I, Ova-2, $\mathrm{Br}-\mathrm{I} \mathrm{Br}-2$ are $\mathrm{HER}-2 /$ neu $^{+}$primary tumour cells from patients with metastatic ovarian and breast cancer. Solid lines: specific staining with scFv(anti-HER-2/neu) plus anti-myc and FITC-anti-mouse Fab'; dotted lines: staining with anti-myc and FITC-anti-mouse Fab'.

chimeric molecule on the cell surface of selected clones as revealed after staining with the anti-Flag-FITC MAb (Figure 3).

\section{Cytokine secretion by the MD.45-HER/ $\zeta$ cells upon recognition of HER-2/neu ${ }^{+}$tumour cells or cell lines}

The functionality of the chimeric receptor was examined by testing the ability of MD.45-HER/ $\zeta$ cells to secrete IL- 2 and IFN- $\gamma$ upon interaction with HER-2/neu ${ }^{+}$cells. As presented in Table $1,24 \mathrm{~h}$ incubation of MD.45-HER/ $\zeta$ cells with the SKOV3 and SKBR3
HER-2/neu ${ }^{+}$tumour cell lines resulted in secretion of relatively high levels of IL-2 (40-100 fold higher compared to background levels (i.e., those achieved with the MD.45-mock cells). That the

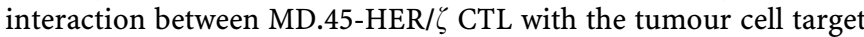
was specific for HER-2/neu was best shown using the HER-2/neu transfectants. Thus, recognition of both ALC-HER and FM3-HER by the MD.45-HER/ $\zeta$ cells resulted in 10-fold higher secretion of IL-2 as compared to the IL-2 levels secreted upon recognition of their mock transfectants. Recognition of HER-2/neu ${ }^{+}$primary tumour cells isolated from patients' ascites led to 15- to 30-fold increased secretion of IL-2 levels as compared to background levels (Table 1). Finally, interaction of MD.45-HER/ $\zeta$ cells with HER-2/neu ${ }^{-}$K562 and Raji cell lines induced only marginal IL-2 secretion comparable to background levels. The specificity of interaction between MD.45-HER/ $\zeta$ hybridoma CTL and HER-2/neu expressing tumour cell lines or primary tumour cells was also confirmed by the fact that an anti-HER-2/neu MAb when present throughout the $24 \mathrm{~h}$ incubation period substantially blocked IL-2 secretion (range of \% inhibition: 64-90) (Table 1).

A similar profile for IFN- $\gamma$ secretion was observed in the same cultures. Thus, the SKBR3 and SKOV3 HER-2/neu-overexpressing tumour cell lines, the HER-2/neu transfectants or the primary HER-2/neu ${ }^{+}$tumour cells stimulated increased secretion of IFN- $\gamma$ by the MD.45-HER/ $\zeta$ transduced CTL hybridoma (Table 2). IFN- $\gamma$ secretion was also greatly inhibited in the presence of the antiHER-2/neu MAb (\% range of inhibition: 69-85) (Table 2).

\section{Cytotoxic activity of MD.45-HER/ $\zeta$ cells}

The functional expression of the $\mathrm{scFv}$ (anti-HER-2/neu)/ $\zeta$ receptor on transduced MD.45 CTL hybridoma was further tested in cytotoxicity experiments against a panel of HER-2/neu ${ }^{+}$and HER$2 / \mathrm{neu}^{-}$tumour cell lines. As shown in Figure 4, all tumour targets expressing HER-2/neu were lysed at relatively high levels (range of $\%$ cytotoxicity at E/T ratio of 20: 37-67). Lysis of HER-2/neu tumour targets was always at very low levels and ranged between 5 and $10 \%$ (E/T:20). That indeed the specificity of lysis was governed by functional expression of the $\mathrm{scFv}$ (anti-HER-2/neu) $/ \zeta$ chimeric gene was further demonstrated (i) by the inhibition of lysis of HER-2/neu ${ }^{+}$targets following the addition of the anti-HER-2/neu MAb (range of \% inhibition: $55-92$ ) and (ii) by the inability of MD.45-mock effectors to lyse HER-2/neu ${ }^{-}$targets. Finally that the killing mediated by MD.45-HER/ $\zeta$ was non-MHC-restricted can be concluded from the fact that HER-2/neu ${ }^{+}$targets from unrelated allogeneic donors were as efficiently lysed as the murine ALC-HER cells.
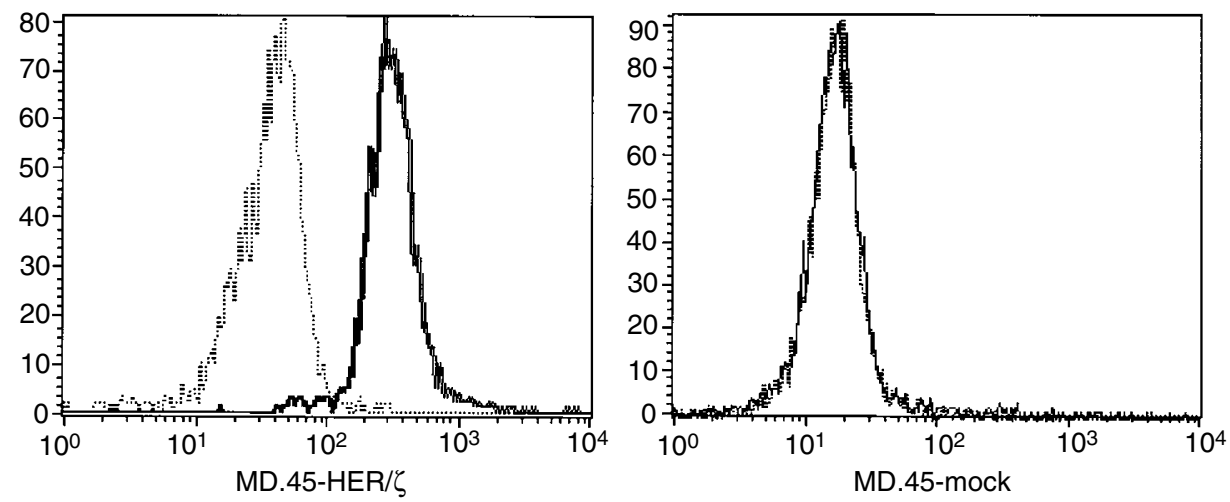

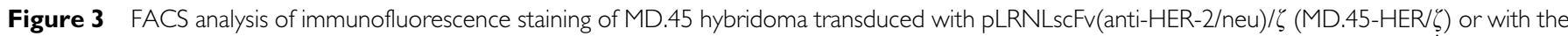
vector alone (MD.45-mock). Expression of scFv(anti-HER-2/neu)/ $\zeta$ was detected with an anti-Flag MAb plus FITC-labelled anti-mouse Fab' (solid lines). Dotted lines: staining with FITC-labelled anti-mouse Fab' alone. 


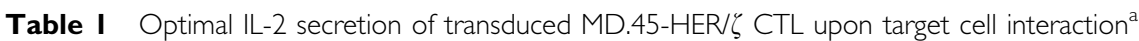

IL-2 production $\left(\mathrm{pg} \mathrm{ml}^{-1}\right)$

\begin{tabular}{|c|c|c|c|c|}
\hline Targets & $\begin{array}{l}\text { HER-2/neu } \\
\text { expression }\end{array}$ & MD.45-HER/ $\zeta$ & 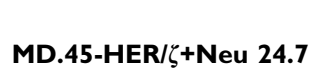 & MD.45-mock \\
\hline $\begin{array}{l}\text { ALC-mock } \\
\text { ALC-HER } \\
\text { FM3-mock }^{c} \\
\text { FM3-HER } \\
\text { SKBR3 } \\
\text { SKOV3 } \\
\text { OVA-1 } \\
\text { OVA-2 } \\
\text { Br- }^{f} \\
\text { Br-2 }^{f} \\
\text { K562 } \\
\text { Raji }\end{array}$ & $\begin{array}{l}- \\
+ \\
- \\
+ \\
+ \\
+ \\
+ \\
+ \\
+ \\
+ \\
-\end{array}$ & $\begin{array}{c}22 \pm 5^{d} \\
290 \pm 50 \\
37 \pm 8 \\
368 \pm 32 \\
1045 \pm 220 \\
960 \pm 180 \\
235 \pm 10 \\
182 \pm 32 \\
650 \pm 75 \\
268 \pm 29 \\
<10 \\
27 \pm 6\end{array}$ & $\begin{array}{c}19 \pm 3(13)^{\mathrm{e}} \\
55 \pm 6(81) \\
39 \pm 7(-5) \\
67 \pm 12(82) \\
375 \pm 52(64) \\
295 \pm 27(69) \\
52 \pm 17(78) \\
39 \pm 22(78) \\
105 \pm 23(90) \\
106 \pm 17(60) \\
<10(0) \\
28 \pm 9(-3)\end{array}$ & $\begin{aligned}< & 10 \\
& 27 \pm 6 \\
& 32 \pm 10 \\
& 39 \pm 6 \\
< & 10 \\
& 23 \pm 5 \\
< & 10 \\
< & 10 \\
& 42 \pm 8 \\
< & 10 \\
< & 10 \\
< & 10\end{aligned}$ \\
\hline
\end{tabular}

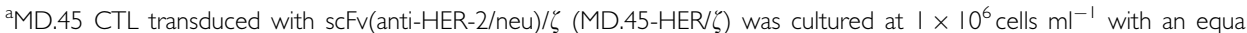
number of tumour cell targets for $24 \mathrm{~h}$ in 24-well plates in I $\mathrm{ml}$ total volume per culture. IL-2 production in the supernatant was measured by ELISA. MD.45-pLRNL is the mock-transduced MD.45 CTL (MD.45-mock). MD.45-HER/ or MD.45mock CTL cultured in the absence of tumour targets produced less than $20 \mathrm{pg} \mathrm{ml}^{-1} \mathrm{IL}-2$. Tumour cells cultured alone produced less than $15 \mathrm{pg} \mathrm{ml}^{-1} \mathrm{LL}-2$. ' 'HER-2/neu expression was determined as described in 'Materials and Methods', 'Transfected ALC and FM3 cells to express HER-2/neu (ALC-HER, FM3-HER) and their mock transfectants (ALC-mock, FM3-mock). ${ }^{d}$ Mean values \pm s.d. from three independently performed experiments. ${ }^{e}$ Percent inhibition of IL-2 production in the presence of $10 \mu \mathrm{g} \mathrm{ml}^{-1}$ of anti-HER-2/neu mAb (Neu 24.7), added at culture initiation, was calculated as follows: $\mathrm{IL}-2 \mathrm{pg} / \mathrm{ml} \mathrm{w} / \mathrm{o} \mathrm{mAb}-\mathrm{IL}-2 \mathrm{pg} / \mathrm{ml}$ with $\mathrm{mA}-\mathrm{blL}-2 \mathrm{pg} / \mathrm{ml} \mathrm{w} / \mathrm{o} \mathrm{mAb} \times 100$. ${ }^{\text {fPrimary }}$ tumour cells collected from peritoneal effusions during routine aspirations from patients with metastatic breast ( $\mathrm{Br}-\mathrm{I}, \mathrm{Br}-2)$ and ovarian (OVA-I, OVA-2) cancer.

Table 2 Optimal IFN- $\gamma$ secretion of transduced MD.45-HER/ $\mathrm{CTL}$ upon target cell interaction

\begin{tabular}{|c|c|c|c|}
\hline \multirow[b]{2}{*}{ Targets } & \multicolumn{3}{|c|}{ IFN- $\gamma$ production $\left(\mathbf{p g ~ m I}{ }^{-1}\right)$} \\
\hline & MD.45-HER/ $\zeta$ & MD.45-HER/ $/$ +Neu 24.7 & MD.45-mock \\
\hline ALC-mock & $<10$ & $<10$ & $<10$ \\
\hline ALC-HER & $87 \pm 7$ & $23 \pm 6(73)$ & $<10$ \\
\hline FM3-mock & $<10^{-}$ & $<10$ & $<10$ \\
\hline FM3-HER & $69 \pm 9$ & $<10$ & $<10$ \\
\hline SKBR3 & $290 \pm 38$ & $45 \pm 12(84)$ & $<10$ \\
\hline SKOV3 & $320 \pm 42$ & $72 \pm 16(77)$ & $<10$ \\
\hline OVA-I & $95 \pm 13$ & $29 \pm 7(69)$ & $17 \pm 2$ \\
\hline OVA-2 & $165 \pm 28$ & $68 \pm 6(59)$ & $<10^{-}$ \\
\hline $\mathrm{Br}-1$ & $77 \pm 6$ & $23 \pm 3(70)$ & $<10$ \\
\hline $\mathrm{Br}-2$ & $92 \pm 7$ & $28 \pm 6(69)$ & $20 \pm 6$ \\
\hline K562 & $<10$ & $<10$ & $<10$ \\
\hline Raji & $<10$ & $<10$ & $<10$ \\
\hline
\end{tabular}

See footnotes of Table I. IFN- $\gamma$ production of either cell type (i.e., transduced MD.45 cells or tumour cell targets) was always $<10 \mathrm{pg} \mathrm{ml}^{-1}$.

\section{Treatment of HER-2/neu ${ }^{+}$tumour cells in SCID mice}

To assess whether MD.45-HER/ $\zeta$ cells had significant in vivo activity against HER-2/neu ${ }^{+}$tumour cells, $1 \times 10^{6}$ murine ALCHER lymphoma cells or an equal number of human FM3-HERmelanoma cells were inoculated s.c. in SCID mice that had been irradiated (200 rad) 1 day before to suppress endogenous NK activity. On the same day with tumour cell inoculation and for the following 2 days, mice were treated with i.p. injections (one

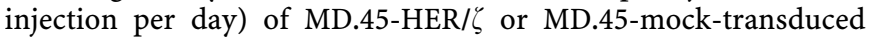
cells. Mice treated with MD.45-HER/ $\zeta$ cells experienced a significantly prolonged survival as compared to those treated with MD.45-mock cells (for both models $>100$ days; $P<0.001$ )
(Figure 5). The specificity of recognition of ALC-HER or FM3-

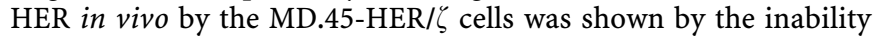
of the later to prevent ALC-mock or FM3-mock growth in the SCID mice (Figure 5).

\section{DISCUSSION}

The HER-2/neu oncoprotein may serve as an excellent target for developing anticancer agents specific for HER-2/neu overexpressing cancer cells. This is based on previously published observations confirming its in vivo and in vitro role as an immunogenic protein. Thus, CTL responses specific for MHC class I HER-2/neu epitopes have been observed in some patients with cancer and HER-2/neu-specific IgG antibodies have been detected in the sera of patients with HER-2/neu ${ }^{+}$cancers (Disis et al, 1994a, b; Yoshino et al, 1994; Knutson et al, 2001). Furthermore, tumour-reactive CTL- and helper T-cell responses could be induced in vitro using various recently identified MHC class I- or class II-binding peptides (Peiper et al, 1997; Brossart et al, 1998; Kobayashi et al, 2000; Sotiriadou et al, 2001; Baxevanis et al, 2002; Perez et al, 2002). Adoptive cellular immunotherapy utilizing patients' $T$ lymphocytes primed in vitro to recognise HER-2/neu epitopes represents one major modality for treating patients carring HER-2/ $\mathrm{neu}^{+}$tumours. In preclinical models, infusion of HER-2/neu reactive $\mathrm{T}$ cells in animals developing HER-2/neu ${ }^{+}$tumours has led to tumour eradication (Knutson et al, 2002). However, adoptive Tcell therapy in patients with HER- $2 /$ neu $^{+}$cancers was relatively unsuccessful due, in part, to the inability to expand tumour antigen-specific $\mathrm{T}$ - cells ex vivo.

To circumvent the limitations associated with the expansion of HER-2/neu ${ }^{+}$tumour-specific T cells, we have adopted an approach in which $\mathrm{T}$ lymphocytes are grafted with a permanent antibodydictated specificity (Eshhar et al, 2001). To this end, we have provided the $\zeta$-chain of TCR with an extracellular recognition domain (scFv) from an anti-HER-2/neu MAb produced by the HB8696 hybridoma. This chimeric construct was stably integrated 


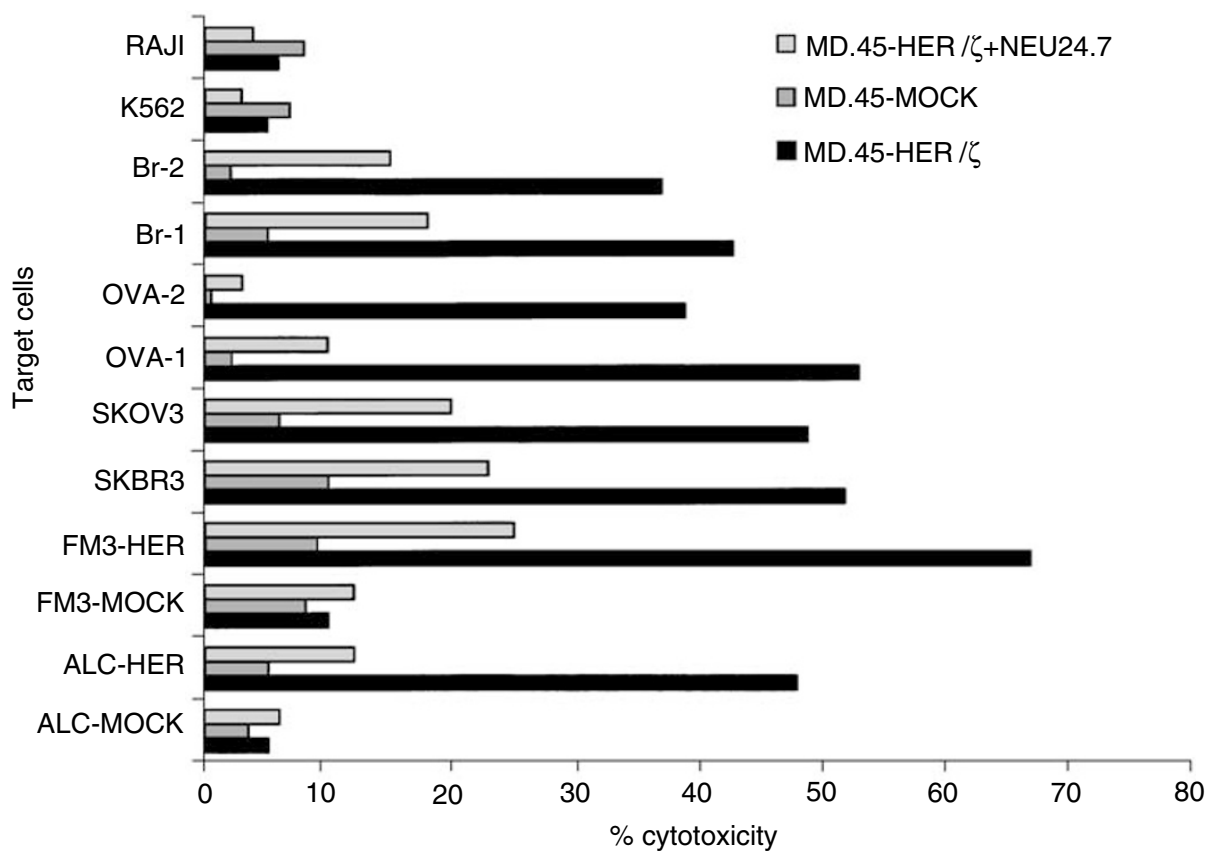

Figure 4 Cytotoxicity of MD.45-HER/ $\zeta$ and MD.45-mock cells against HER-2/neu ${ }^{+}$(ALC-HER, FM3-HER, SKBR3, SKOV3, Ova- I, Ova-2, Br-I, Br-2) and HER-2neu ${ }^{-}$(ALC-mock FM3-mock, K562, Raji) targets tested in a $4 \mathrm{~h}$ cytotoxicity assay. Blocking of cytolysis mediated by MD.45-HER/ $\gamma$ cells was performed with an anti-HER-2/neu MAb (Neu 24.7) at a concentration of $10 \mu \mathrm{g} \mathrm{ml}{ }^{-1}$. The specific ${ }^{59} \mathrm{Cr}$ release is depicted at E/T:20. Mean values from triplicate cultures are shown. The s.d. (not shown) never exceeded 10\% of the mean values. Results from one representative experiment out of three performed are shown.

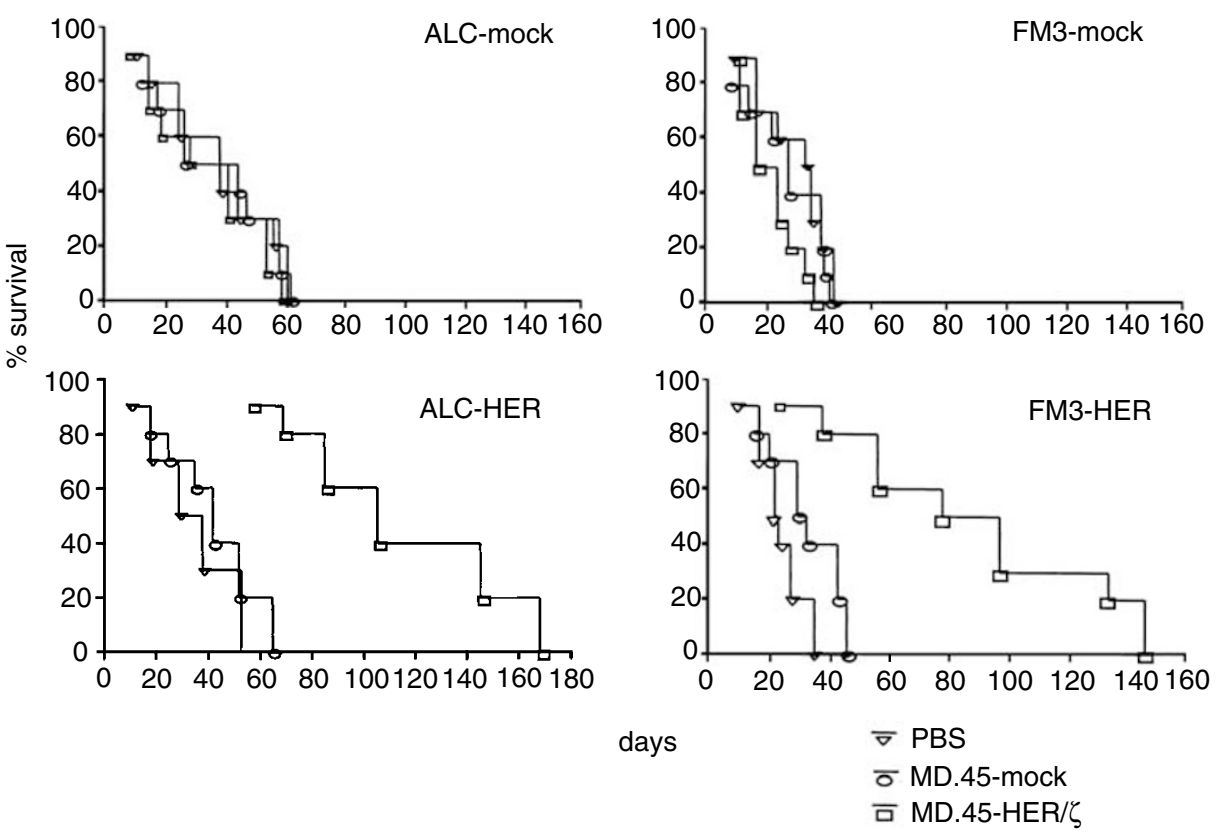

Figure 5 Survival of SCID mice after subcutaneous injection (day I) with human melanoma FM3 (FM3-HER, FM3-mock) or murine leukaemic ALC (ALCHER, ALC-mock) cell lines. On the same day (day I) and for the following 2 days (days 2 and 3) mice were treated with PBS or MD45 cells transduced

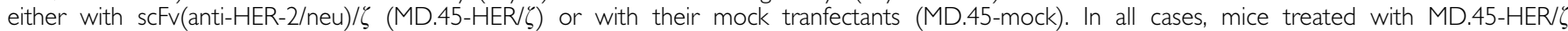
demonstrated a significant increase in survival compared to the other groups $(P<0.0 \mathrm{I})$.

and expressed by retroviral gene transfer in the MD.45 CTL hybridoma. MD.45 cells transduced to express the scFv(anti-HER$2 / \mathrm{neu}) / \zeta$ could specifically recognise HER-2/neu ${ }^{+}$breast and ovarian tumour cell lines as well as HER-2/neu ${ }^{+}$primary tumour cells from patients with metastatic breast and ovarian cancer. Such recognition led to lysis of HER-2/neu ${ }^{+}$tumour targets and also to secretion of IL- 2 and IFN- $\gamma$ by the MD.45-HER effector CTL. The combined induction of cytokine secretion and cytotoxicity by the redirected MD.45 cells is an important issue supporting the use of our chimeric receptor gene for transducing patients' PBL to be used in cellular adoptive immunotherapy. In this way, besides direct tumour cell lysis by transduced $\mathrm{CD}^{+} \mathrm{T}$ cells, release of 
cytokines by transduced $\mathrm{CD}^{+} \mathrm{T}$ cells upon specific target cell interaction may also contribute to tumour growth inhibition as well as induction of NK/LAK activities. These lytic activities may result in elimination of tumour cells that lack- or downregulate the relevant (i.e., HER-2/neu) tumour-associated antigen (Pawelec et al, 1997).

Chimeric constructs containing a single-chain antibody directed against the human ErbB-2 receptor have been previously demonstrated to redirect $\mathrm{T}$-cell specificity towards mouse epithelial cells transformed to express the human ErbB-2 and human ErbB-2 ${ }^{+}$ MDA-MB453 breast cancer cells (Moritz et al, 1994; Altenschmidt et al, 1997). In these studies, the recognition function was contributed by the scFv domain derived from the MAb FRP5 (Wels et al, 1992), specific for the extracellular domain of ErbB-2, whereas the $\zeta$-chain of the TCR represented the signalling component. In the present study, we designed a new construct using the scFv from another anti-HER-2/neu Mab produced by the HB8696 hybridoma. Competitive inhibition studies on HER-2/ neu $^{+}$tumours utilizing both FRP5- and HB8696-derived scFvs (one FITC-conjugated and the other nonlabelled) could probably clarify whether these recognise the same or different HER-2/neu epitopes. However, irrespective of the epitope recognised, our MD.45 effectors transduced to express this particular $\mathrm{scFv}$ (fused to the TCR $\zeta$-chain) were capable of recognising and lysing HER-2/neu ${ }^{+}$ tumour cell lines from different types of cancer as well as primary HER-2/neu ${ }^{+}$tumour cells from metastatic breast and ovarian cancers. Given the fact that MD.45 cells expressing this construct were also active in vivo by inhibiting the growth of HER-2/neu ${ }^{+}$ tumour cells (see below), it becomes evident that our HER/ $\zeta$ construct offers a novel and promising tool for future therapeutic interventions in cancer.

The in vivo antitumour activity of MD.45-HER/ $\zeta$ was evaluated in SCID mice/tumour models. Murine ALC or human FM3 tumour cells either transfected to express HER-2/neu or mock-transfected were inoculated into SCID mice. MD.45-HER/ $\zeta$ cells, when implanted simultaneously with the HER-2/neu ${ }^{+}$tumour cells and for the following 2 days (one injection per day) considerably slowed the growth of these tumour cells. MD.45-HER/ $\zeta$ cells did not exhibit any therapeutic effect when mice were inoculated with ALC or FM3 tumour cells not expressing HER-2/neu (i.e., ALCmock or FM3-mock cells) indicating the specificity of the in vivo antitumour response. This was confirmed by demonstrating the inability of MD.45-mock cells to slow the growth of ALC-HER or FM3-HER tumour cells in SCID mice. Another interesting point which came out from our studies is that the MD.45-HER/ $/ \zeta$ cells must have the ability to traffic and target tumour cells in vivo,

\section{REFERENCES}

Abken H, Hombach A, Reinhold U, Ferrone S (1998) Combined T-cell- and antibody- based immunotherapy outsmart tumour cells. Immunol Today 19: $1-5$

Altenschmidt U, Klundt E, Grower B (1997) Adoptive transfer of in vitrotargeted, activated $\mathrm{T}$ lymphocytes results in total tumour regression. $J$ Immunol 159: 5509-5515

Baxevanis CN, Gritzapis AD, Tsitsilonis OE, Katsoulas H, Papamichail M (2002) HER-2/neu-derived peptide epitopes are also recognized by cytotoxic CD3+CD56+ (natural killer T) lymphocytes. Int J Cancer 98: $864-872$

Baxevanis CN, Voutsas IF, Tsitsilonis OE, Gritzapis AD, Sotiriadou R, Papamichail M (2000) Tumour-specific CD4+ T lymphocytes from cancer patients are required for optimal induction of cytotoxic $\mathrm{T}$ cells against the autologous tumour. J Immunol 164: 3902-3912

Brocker T, Karjalainen K (1997) Adoptive tumour immunity mediated by lymphocytes bearing modified antigen-specific receptors. Adv Immunol 68: $257-269$ since these were given i.p., whereas both the ALC and FM3 tumour cells were given s.c. It is also important to note that the in vivo antitumour activity was observed in the absence of exogenously added IL-2 demonstrating that the IL-2 (and most probably also IFN- $\gamma$ ) produced by the MD.45-HER/ $\zeta$ cells upon encounter of the tumour cells (as shown in the in vitro experiments) was sufficient for supporting their in vivo activity. This is an important issue since, clinically, IL-2 administration has been associated with significant toxicity (Rosenberg et al, 1994). Finally, although survival was enhanced three-fold, all mice eventually died from their ALC-HER ${ }^{+}$or FM3-HER ${ }^{+}$tumours. FACS analysis of these tumour cells showed continued presence of HER-2/neu expression (data not shown). This suggests that antigen downregulation was not the mechanism of escape in this particular model. Another possibility, although not tested herein, could be that the injected MD.45-HER/ $\zeta$ effectors underwent IL-2 dependent, Fas-mediated activation-induced cell death.

Complete tumour eradication may require repeated treatment, combination of i.p. and i.v. therapy, or combinations with other treatment approaches. With respect to this, therapy strategies using a second round of injections with MD.45-HER/ $/ \zeta$ cells 1 month after tumour cell inoculation or combined treatment with HER-2/neu peptide-specific CTL and MD.45-HER/ $\zeta$ cells are under investigation in our laboratory. Tumour therapy using a variety of chimeric receptors targeting different antigens may also be necessary should antigen downregulation or in vivo immunoselection of HER-2/neu negative cells becomes evident.

In summary, the data from this report describe a novel chimeric receptor construct for the gene therapeutic approach to HER-2/ neu $^{+}$cancers. The cells expressing this chimeric construct respond specifically to HER-2/neu ${ }^{+}$tumours in vitro and are also therapeutically effective in vivo. Current efforts are focused on enhancing transduction efficiencies and chimeric gene expression in primary $\mathrm{T}$ cells, as well as bone marrow stem cells, to maximise the applicability of this technology.

\section{ACKNOWLEDGEMENTS}

We thank Miss Joanna Doukoumopoulou for her excellent secretarial assistance. This work was supported by grants from the Regional Operational Program Attika No. 20, MIS code 59605GR to MP and from the GSRT Program No. 97 EKBAN-19 to $\mathrm{CNB}$.

Brossart P, Stuhler G, Flad T, Stevanovic S, Rammensee H-G, Kanz L, Brugger W (1998) Her-2/neu-derived peptides are tumour associated antigens expressed by human renal cell and colon carcinoma cell lines and are recognized by in vitro induced specific cytotoxic T lymphocytes. Cancer Res 58: $732-736$

Brown NH, Kafatos FC (1988) Functional cDNA libraries from Drosophila embryos. J Mol Biol 203: 425-437

Disis ML, Calenoff E, McLaughlin G, Murphy AE, Chen W, Grower B, Jeschke M, Lyndon N, McGlynn E, Livingston RB, Moe R, Cheever MA (1994a) Existent T-cell and antibody immunity to HER-2/neu protein in patients with breast cancer. Cancer Res 54: 16-22

Disis ML, Smith JW, Murphy AE, Chen W, Cheever MA (1994b) In vitro generation of human cytolytic T-cells specific for peptides derived from the HER-2/neu protooncogene protein. Cancer Res 54: 1071-1076

EMBO Practical Course. Making Antibodies in Bacteria and on Phages (IRBM Rome) 1991 
Eshhar Z, Waks T, Bendavid A, Schindler DG (2001) Functional expression of chimeric receptor genes in human T cells. J Immunol Methods 248: $67-76$

Eshhar Z, Waks T, Gross G, Schindler DG (1993) Specific activation and targeting of cytotoxic lymphocytes through chimeric single chains consisting of antibody-binding domains and the $\gamma$ or $\zeta$ of the immunoglobulin and T-cell receptors. Proc Natl Acad Sci USA 90: $720-724$

Evan GI, Lewis GK, Ramsay G, Bishop JM (1985) Isolation of monoclonal antibodies specific for human c-myc proto-oncogene product. Mol Cell Biol 3: $3610-3616$

Fisk B, Blevins TL, Wharton JT, Ioannides CG (1995) Identification of an immunodominant peptide of HER-2/neu protooncogene recognized by ovarian tumour-specific cytotoxic T lymphocyte lines. J Exp Med 181: $2109-2717$

Haynes NM, Snook MB, Tragani JA, Cerruti L, Jane SM, Smyth M, Darcy DK (2001) Redirecting mouse CTL against colon carcinoma: superior signaling efficacy of single-chain variable domain chimeras containing TCR- $\zeta$ vs FceRI- $\gamma$. J Immunol 166: $182-187$

Hoogenboom HR, Griffiths AD, Johnson KS, Chiswell DJ, Hudson P, Winter G (1991) Multi-subunit proteins on the surface of filamentous phage methodologies for displaying antibody (Fab) heavy and light chains. Nucleic Acids Res 19: 4133-4137

Hung M-C, Lau Y-K (1999) Basic science of HER-2/neu: a review. Semin Oncol 26: $51-59$

Hwu P, Yang JC, Lowherd R, Treisman J, Shafer GE, Eshhar Z, Rosenberg SA (1995) In vivo antitumour activity of T cells redirected with chimeric antibody/T-cell receptor genes. Cancer Res 55: 3369-3373

Kabat EA, Wu TT, Reid-Miller M, Perry HM, Gottesman KS (1991) Sequences of Proteins of Immunological Interest. Bethesda, MD: National Institutes of Health

Knutson KL, Almand B, Mankoff DA, Schiffman K, Disis ML (2002) Adoptive T-cell therapy for the treatment of solid tumours. Expert Opin Biol Ther 2: 55-66

Knutson KL, Schiffman K, Disis ML (2001) Immunization with a HER-2/ neu helper peptide vaccine generates HER-2/neu CD8 T-cell immunity in cancer patients. J Clin Invest 107: 477-484

Kobayashi H, Wood M, Song Y, Appella E, Celis E (2000) Defining promiscuous MHC class II helper T-cell epitopes for the HER2/neu tumour antigen. Cancer Res 60: 5228-5236

Laemmli UK (1970) Cleavage of structural proteins during the assembly of the head of bacteriophage T4. Nature 27: 680-685

Maher J, Breutjens RJ, Gunset G, Riviere I, Sadelain M (2002) Human Tlymphocyte cytotoxicity and proliferation directed by a single chimeric TCR $/$ /CD28 receptor. Nat Biotech 20: $70-75$

Mamalaki A, Trakas N, Tzartos SJ (1993) Bacterial expression of a scFv fragment which efficiently protects the acetylcholine receptor against antigenic modulation caused by myasthenic antibodies. Eur J Immunol 23: $1839-1845$

Maxwell-Armstrong CA, Durrant LG, Scholefield JH (1998) Colorectal cancer vaccines. Br J Surg 85: $149-155$

Moritz D, Wels W, Mattern J, Grower B (1994) Cytotoxic T lymphocytes with a grafted recognition specificity for ERBB2-expressing tumour cells. Proc Natl Acad Sci USA 91: 4318-4322

Niederman TMJ, Ghogawala Z, Carter BS, Tompkins HS, Russell MM, Mulligan RC (2002) Antitumour activity of cytotoxic T lymphocytes engineered to target vascular endothelial growth factor receptors. Proc Natl Acad Sci USA 99: 7009-7014

Pauletti G, Godolphin W, Press MF, Slamon DJ (1996) Detection and quantitation of HER-2/neu gene amplification in human breast cancer and archival material using fluorescence in situ hybridization. Oncogene 13: $63-69$

Pawelec C, Zeuthen J, Kiessling R (1997) Escape from host-antitumour immunity. Crit Rev Oncog 8: 111-141

Pear WS, Nolan GP, Scott ML, Baltimore D (1993) Production of high-titer helper-free retroviruses by transient transfection. Proc Natl Acad Sci USA 90: $8392-8397$

Peiper M, Goedegebuure RS, Lineham DC, Ganguly E, Douville C, Eberlein TJ (1997) The HER-2/neu-derived peptide p654-662 is a tumour- associated antigen in human pancreatic cancer recognized by cytotoxic T lymphocytes. Eur J Immunol 27: 1115-1123

Perez SA, Sotiropoulou PA, Sotiriadou NN, Mammalaki A, Gritzapis AD, Echner H, Voelter W, Pawelec G, Papamichail M, Baxevanis CN (2002) HER-2/neu-derived peptide $884-899$ is expressed by human breast, colorectal and pancreatic adenocarcinomas and is recognized by invitro-induced specific CD4+ T cell clones. Cancer Immunol Immunother 50: $615-624$

Roberts MR, Looke KS, Tran A-C, Smith KA, Lin WL, Wang M, Dull TJ, Farson D, Zsebo KM, Finer MH (1998) Antigen-specific cytolysis by neutrophils and NK cells expressing chimeric immune receptors bearing $\zeta$ or $\gamma$ signaling domains. J Immunol 161: 375-384

Rongcun Y, Salazar-Onfray F, Charo J, Malmberg K-J, Evrin K, Maes H, Kono K, Hising C, Petersson M, Larsson O, Lan L, Appella E, Sette A, Celis E, Kiessling R (1999) Identification of new HER-2/neu- derived peptide epitopes that can elicit specific CTL against autologous and allogeneic carcinomas and melanomas. I Immunol 163: 1037-1044

Rosenberg SA, Yannelli JR, Yang JC, Topalian SL, Schwartzentruber DJ Weber JS, Parkinson DR, Seipp CA, Einhorn JH, White PE (1994) Treatment of patients with metastatic melanoma with autologous tumour-infiltrating lymphocytes and interleukin 2. J Natl Cancer Inst 86: $1159-1164$

Sanger F, Nicklen SA, Coulson AR (1977) DNA sequencing with chainterminating inhibitors. Proc Natl Acad Sci USA 74: 5463-5469

Shi T, Eaton MA, Ring BD (1991) Selection of hybrid hybridomas by flow cytometry using a new combination of fluorescent vital stains. J Immunol Methods 141: $165-175$

Slamon DJ, Godolphin W, Jones LA, Holt JA, Wong SG, Keith DE, Levin WJ, Stuart SG, Udove J, Ullrich A, Press MF (1989) Studies of the HER-2/ neu proto-oncogene in human breast and ovarian cancer. Science (Washington DC) 244: 707-710

Slamon DJ, Leyland-Jones B, Shak S, Fuchs H, Paton V, Bajamonde A, Fleming T, Eiermann W, Voelter J, Pegram M, Baselga J, Norton L (2001) Use of chemotherapy plus a monoclonal antibody against HER2 for metastatic breast cancer that overexpress HER2 N. Engl J Med 344: 783

Sotiriadou R, Perez SA, Gritzapis AD, Sotiropoulou PA, Echner A, Heinze S, Mamalaki A, Pawelec G, Voelter W, Baxevanis CN, Papamichail M (2001) Peptide HER2 (776-788) represents a naturally processed broad MHC class II-restricted T cell epitope. Brit J Cancer 85: 1527 - 1534

Tsantili P, Tzartos S, Mamalaki A (1999) High affinity scFv antibody fragments protecting the human uscotinic acetylcholine receptor. $J$ Neuroimmunol 94: 15-27

Uherek C, Tonn T, Uherek B, Becker S, Schnierle B, Klingermann H-G Wels W (2002) Retargeting of natural killer-cell cytolytic activity to ErbB2-expressing cancer cells results in efficient and selective tumour cell destruction. Blood 100: $1265-1273$

Ward ES, Gussow D, Griffiths AD, Jones PT, Winter G (1989) Binding activities of a repertoire of single immunoglobulin variable domains secreted from Escherichia coli. Nature 341: 544-546

Weijtens MEM, Willemsen RA, Valerio D, Stam K, Bolhuis RLH (1996) Single chain $\mathrm{Ig} / \gamma$ gene-redirected human $\mathrm{T}$ lymphocytes produce cytokines, specifically lyse tumour cells, and recycle lytic capacity. J Immunol 157: 836-843

Wels W, Harwerth I-M, Mueller M, Grower B, Hynes NE (1992) Selective inhibition of tumour cell growth by a recombinant single-chain antibody-toxin specific for the erbB-2 receptor. Cancer Res 52: $6310-$ 6317

Workman P, Twentyman P, Balkwill F, Balmain A, Chaplin D, Double J, Embleton J, Newell D, Raymond R, Stables J, Stephens T, Wallace J (1998) United Kingdom Co-ordinating Committee on Cancer Research (UKCCCR) Guidelines for the Welfare of Animals in Experimental Neoplasia (Second Edition). Br J Cancer 77: 1 - 10

Yamanaka Y, Friess H, Kobrin MS, Buchler M, Kunz J, Beger HG, Korc M (1993) Overexpression of HER-2/neu protooncogene in human pancreatic carcinoma. Hum Pathol 24: 1127-1132

Yoshino IM, Goedegebuure PS, Peoples GE, Parish AS, DiMaio JM, Lyerly HK, Gazdar AF, Eberlein TJ (1994) HER-2/neu-derived peptides are shared antigens among non-small cell lung cancer and ovarian cancer. Cancer Res 54: $3387-3390$ 